\title{
Association of miR-196a2 rs11614913 and miR-499 rs3746444 polymorphisms with cancer risk: a meta-analysis
}

\author{
Wanjun Yan ${ }^{1}$, Xiaoyan Gao ${ }^{1}$ and Shuqun Zhang ${ }^{1}$ \\ ${ }^{1}$ Department of Oncology, The Second Affiliated Hospital of Xi'an Jiaotong University, Xi'an, Shaanxi 710004, P.R. China \\ Correspondence to: Shuqun Zhang, email: zhangshuqun1971@aliyun.com \\ Keywords: miRNA, single nucleotide polymorphism, cancer susceptibility, meta-analysis
}

Received: March 08, $2017 \quad$ Accepted: August 29, $2017 \quad$ Published: November 20, 2017

Copyright: Yan et al. This is an open-access article distributed under the terms of the Creative Commons Attribution License 3.0 (CC BY 3.0), which permits unrestricted use, distribution, and reproduction in any medium, provided the original author and source are credited.

\section{ABSTRACT}

Background: MicroRNAs (miRNAs) are small non-coding RNA molecules, which participate in diverse biological processes and may regulate tumor suppressor genes or oncogenes. Rs11614913 in miR-196a2 and rs3746444 in miR-499 are shown to associate with increased/decreased cancer risk. This meta-analysis was performed to systematically assess the overall association.

Materials and Methods: We searched Pubmed, Web of Knowledge, EMBASE, Chinese National Knowledge Infrastructure (CNKI) databases until December 2016 to identify eligible studies. Odds ratios (ORs) and $95 \%$ confidence intervals (CIs) were used to estimate the strength of the associations.

Results: We assessed published studies of the association between these microRNA polymorphisms and cancer risk from 56 studies with 21958/26436 cases/ controls for miR-196a2 and from 37 studies with 13759/17946 cases/controls for miR-499. The results demonstrated that miR-196a2 rs11614913 was significantly associated with a decreased cancer risk, in particular with a decreased risk for colorectal cancer and gastric cancer, or for Asian population subgroup. In addition, miR-499 rs3746444 polymorphism was observed as a risk factor for cancers, in particular, for breast cancer, or for in the Asian population.

Conclusions: Our meta-analysis suggests that the rs11614913 most likely contributes to decreased susceptibility to cancer, especially in Asians and colorectal cancer and gastric cancer, and that the rs3746444 may increase risk for cancer. Furthermore, more well-designed studies with large sample size are still necessary to further elucidate the association between polymorphisms and different kinds of cancers risk.

\section{INTRODUCTION}

Cancer is reportedly one of the major causes of death among human worldwide [1]. According to GLOBOCAN 2012 report, there were 14.1 million new cases and 8.2 million deaths in 2012 [2]. Recently reported, as a very complex genetic disease, the mechanism of cancer has not been completely elucidated. Moreover, studies have suggested that cancer development results from geneenvironment interactions [3].

MicroRNAs (miRNAs) are a class of endogenous small single-stranded, long non-coding RNA molecules, which play critical roles in a extensive range of biologic and pathologic processes, especially in carcinogenesis [4-5]. Accumulating studies indicates that a single miRNA cantarget 200 genes, and approximately $20 \%$ of human genes are regulated by the mature miRNA molecules [6]. More than half of miRNAs genes are located in cancerrelated genomic regions, indicating that these miRNAs may play a more important key role in the etiology, tumorigenesis, development and prognosis of human cancers than previous research [7].

Single nucleotide polymorphisms (SNPs) occurring in the miRNA gene region may influence the function of specific miRNA molecules and the genetic variation, which are associated with cancer susceptibility 
through altering miRNA molecules expression [8-9]. Recently, miR-196a2C.T (rs11614913) and miR-499 A.G (rs3746444) have been reported to demonstrate the association with malignant tumors susceptibility [10-17]. For instance, Min et al. [11] demonstrates that the miRNA variants could affect the development of colorectal cancer in the Korean, while Georgeh et al. [17]. showed miR196a2C.T (rs11614913)and miR-499 A.G (rs3746444) revealed significant risk for developing prostate cancer in North Indian. However, the consequences of these relevant studies remain incomprehensive and controversial. To the best of our knowledge, there is no systematic and comprehensive reports or studies regarding the impact of miR196a2 and miR-499 variants on overall cancer risk in world wide population. Hence, we performed a meta-analysis to clarify the associaton between the miR196a2C.T (rs11614913)and miR-499 A.G (rs3746444) polymorphisms with cancer susceptibility.

\section{MATERIALS AND METHODS}

\section{Publication search}

We carried out a search in PubMed, ISI Web of Knowledge, EMBASE, Chinese National Knowledge Infrastructure(CNKI) databases for all relevant reports using the key words "microRNA 192" OR "microRNA-192" OR “miR-192” OR “rs11614913” OR “microRNA 499” OR “microRNA-499” OR “miR-499” OR “ rs3746444”) AND ("polymorphism” OR “SNP” OR "variation” OR "locus” OR "mutation") AND (“cancer" OR "tumor" OR "malignancy" OR “carcinoma” OR “neoplasm”(updated to Dec 30, 2016). The search was limited to English language papers and human subject studies. We evaluated potentially relevant publications by examining their titles and abstracts, thereafter all studies matching the eligible inclusion criteria were retrieved.

\section{Selection criteria}

The following criteria were used to select studies for further meta-analysis: (a) about the miR-196a2 rs11614913/miR-499 rs3746444 polymorphisms and cancer risk, (b) full-text study, (c) from a case-control designed study, (d) genotype frequencies available, (e) sufficient published data for estimating an odds ratio (OR) with $95 \%$ confidence interval (CI).

Accordingly, the following exclusion criteria were also used: (a) the design of the experiments were not casecontrol studies; (b) the source of cases and controls, and other essential information were not provided; (c) reviews and duplicated publications.

\section{Data extraction}

All data were independently abstracted in duplicate by two investigators (Yan and Zhang) using a standard protocol and data-collection form according to the inclusion criteria listed above. The following information was sought from each publication: the first author's name, year of publication, country of origin, ethnicity, cancer type, source of control (population- or hospital-based controls), genotyping method and number of cases and controls miR-196a $2 \mathrm{C} / \mathrm{T}$ and/or miR-499 G/A genotypes, respectively (Table 1). Different ethnicity descents were categorized as Caucasian and Asian.

\section{Statistical analysis}

We first assessed the departure of frequencies of miRNA polymorphisms from expectation under HardyWeinberg equilibrium (HWE) for each study by using the goodness-of-fit test (chisquare or Fisher exact test) in controls. ORs corresponding to $95 \%$ CIs were calculated to access the strength of association between microRNA SNPs and cancer risks. Pooled ORs were obtained from combination of single study by heterozygote comparison (CT vs. CC for rs11614913; AG vs. AA for rs3746444), homozygote comparison (TT vs. CC for rs11614913; GG vs. AA for rs3746444), dominant model (TT + TC vs. CC for rs 11614913; GG + AG vs. AA for rs3746444), recessive model (TT vs. CC $+\mathrm{CT}$ for rs11614913; GG vs. $\mathrm{AG}+\mathrm{AA}$ for rs3746444) and allelic model (T vs. C for rs11614913; G vs. A for rs3746444) respectively. For each genetic comparison model, subgroup analysis according to ethnicity was investigated to estimate ethnic-specific ORs for Asian and Caucasian. Meanwhile stratified analyses by tumor type or control characteristics were also applied for each genetic comparison model.

Statistical heterogeneity between studies was checked by Cocharan's chi-square based $Q$-test [18] and quantified by $\mathrm{I}^{2}$. If the $P$-value for heterogeneity was $<0.05$, or if $\mathrm{I}^{2}$ was $\geq 50 \%$, indicating substantial heterogeneity among studies, then a random-effect model using the DerSimonian and Laird method [31], which yielded wider CIs, was chosen to calculate the pooled OR; otherwise, a fixed-effect model using the Mantel-Haenszel method [19] was used. One-way sensitivity analyses were performed to assess the stability of the meta-analysis results [20]. Potential publication bias was estimated using Egger's linear regression test by visual inspection of the Funnel plot. All $P$ value $<0.05$ was used as an indication of potential publication bias [21].

All statistical analyses were carried out with the review manager version 5.2 (Revman; The Cochrane Collaboration, Oxford, UK). All $P$ values in the metaanalysis were two-sided, and $P$ value less than 0.05 were considered significant.

\section{RESULTS}

\section{Characteristics of the studies}

In total, 462 published studies were obtained though literature search, including the PubMed, EMBASE and 
Table 1: Summary of published studies included

\begin{tabular}{|c|c|c|c|c|c|c|c|c|}
\hline & Author & Year & Race & Cancer type & Control & Method & Case/control & Polymorphism site \\
\hline 1 & Ahn [22] & 2012 & Asian & gastric cancer & PB & PCR-RFLP & $461 / 477$ & rs11614913, rs3746444 \\
\hline 2 & Alshatwi [23] & 2012 & Asian & Breast Cancer & PB & PCR-RFLP & $89 / 100$ & rs11614913, rs3746444 \\
\hline 3 & B.Zhou [24] & 2011 & Asian & $\begin{array}{l}\text { Cervical Squamous } \\
\text { Cell Carcinoma }\end{array}$ & PB & PCR-RFLP & $226 / 309$ & rs11614913, rs3746444 \\
\hline 4 & Bansal [25] & 2014 & Asian & breast cancer & PB & PCR-RFLP & $121 / 164$ & rs11614913, rs3746444 \\
\hline 5 & Behnaz [26] & 2016 & Caucasian & $\mathrm{HCC}$ & PB & PCR & $103 / 432$ & rs 11614913 \\
\hline 6 & Brajušković [27] & 2015 & Caucasian & prostate cancer & PB & PCR-RFLP & $355 / 312$ & rs11614913, rs3746444 \\
\hline 7 & Catucci [28] & 2012 & Caucasian & breast cancer & PB & PCR-RFLP & $1894 / 2760$ & rs11614913, rs3746444 \\
\hline 8 & cheng [29] & 2015 & Asian & gastric cancer & HB & MassARRAY & $363 / 969$ & rs3746444 \\
\hline 9 & Chu [30] & 2012 & Asian & Oral Cancer & PB & PCR-RFLP & $470 / 425$ & rs11614913, rs3746444 \\
\hline 10 & D. Li [31] & 2015 & Asian & $\mathrm{HCC}$ & PB & RT-PCR & $184 / 184$ & rs3746444 \\
\hline 11 & Dai [32] & 2016 & Asian & breast cancer & HB & MassARRAY & $560 / 583$ & rs11614913, rs3746444 \\
\hline 12 & Deng [33] & 2015 & Asian & bladder cancer & PB & PCR-RFLP & $159 / 298$ & rs11614913, rs3746444 \\
\hline 13 & Dominik [34] & 2011 & Caucasian & Breast Cancer & PB & PCR-RFLP & $187 / 171$ & rs 11614913 \\
\hline 14 & Dou [35] & 2010 & Asian & glioma & PB & PCR-RFLP & $643 / 656$ & rs11614913 \\
\hline 15 & Eman [36] & 2016 & Caucasian & Hepatic/Renal Cancer & PB & RT-PCR & $65 / 150$ & rs11614913, rs3746444 \\
\hline 16 & $\mathrm{Gu}[37]$ & 2013 & Asian & esophageal cancer & PB & PCR-RFLP & $380 / 380$ & rs11614913, rs3746444 \\
\hline 17 & H. Chen [38] & 2011 & Asian & colorectal cancer & HB & PCR-LDR & $126 / 407$ & rs 11614913 \\
\hline 18 & H. Zhao [39] & 2016 & Asian & breast cancer & HB & RT-PCR & $114 / 114$ & rs11614913 \\
\hline 19 & Hashemi [40] & 2016 & Asian & prostate cancer & PB & PCR-RFLP & $169 / 182$ & rs11614913, rs3746444 \\
\hline 20 & Hikmet [41] & 2011 & Caucasian & $\mathrm{HCC}$ & PB & PCR-RFLP & $222 / 222$ & rs3746444 \\
\hline 21 & Hong [42] & 2011 & Asian & Lung Cancer & HB & PCR-RFLP & $406 / 428$ & rs 11614913 \\
\hline 22 & $\mathrm{Hu}[43]$ & 2013 & Asian & Glioma & $\mathrm{HB}$ & PCR-RFLP & $680 / 690$ & rs11614913, rs3746444 \\
\hline 23 & J. Shi [44] & 2015 & Asian & gastric cancer & PB & RT-PCR & $448 / 452$ & rs3746444 \\
\hline 24 & $\operatorname{Kim}[45]$ & 2012 & Asian & colorectal cancer & PB & PCR-RFLP & $201 / 159$ & rs11614913, rs3746444 \\
\hline 25 & Kim [46] & 2011 & Asian & lung cancer & PB & PCR-RFLP & $654 / 640$ & rs 11614913 \\
\hline 26 & Kou [47] & 2014 & Asian & $\mathrm{HCC}$ & PB & PCR-RFLP & $271 / 532$ & rs11614913, rs3746444 \\
\hline 27 & Kshitij [48] & 2010 & Asian & gallbladder cancer & PB & PCR-RFLP & $230 / 230$ & rs11614913, rs3746444 \\
\hline 28 & Kuo [49] & 2014 & Asian & $\mathrm{HCC}$ & PB & PCR-RFLP & $188 / 377$ & rs11614913, rs3746444 \\
\hline 29 & $\operatorname{Li}[50]$ & 2015 & Asian & $\begin{array}{l}\text { non-Hodgkin } \\
\text { lymphoma }\end{array}$ & PB & RT-PCR & $318 / 320$ & rs 11614913 \\
\hline 30 & Linhare [51] & 2012 & Caucasian & Breast cancer & PB & TaqMan & $388 / 388$ & rs11614913 \\
\hline 31 & LIU [52] & 2010 & Asian & $\mathrm{HCC}$ & HB & PCR-RFLP & $310 / 222$ & rs 11614913 \\
\hline 32 & $\operatorname{Lv}[53]$ & 2013 & Asian & colorectal cancer & PB & PCR-RFLP & $353 / 540$ & rs 11614913 \\
\hline 33 & M. Zhang [54] & 2012 & Asian & Breast Cancer & PB & PCR-RFLP & $252 / 248$ & rs 11614913 \\
\hline 34 & Masaaki [55] & 2010 & Asian & gastric cancer & PB & PCR-RFLP & $552 / 697$ & rs11614913, rs3746444 \\
\hline 35 & Min [11] & 2012 & Asian & Colorectal Cancer & PB & PCR-RFLP & $446 / 502$ & rs11614913, rs3746444 \\
\hline 36 & Morales [56] & 2016 & Caucasian & Breast cancer & PB & TaqMan & $440 / 807$ & rs11614913 \\
\hline
\end{tabular}




\begin{tabular}{|c|c|c|c|c|c|c|c|c|}
\hline 37 & N. Wang [57] & 2014 & Asian & ESCC & $\mathrm{PB}$ & PCR-LDR & $597 / 597$ & rs11614913 \\
\hline 38 & Ni [58] & 2015 & Asian & $\begin{array}{l}\text { endometrial/ovarian } \\
\text { cancer }\end{array}$ & $\mathrm{PB}$ & PCR & $141 / 100$ & rs11614913, rs3746444 \\
\hline 39 & Omrani [59] & 2014 & Asian & breast cancer & PB & PCR & $236 / 203$ & rs11614913, rs3746444 \\
\hline 40 & P. Dikaiakos [60] & 2015 & Caucasian & colorectal cancer & PB & PCR-RFLP & $157 / 299$ & rs11614913 \\
\hline 41 & P. Li [61] & 2014 & Asian & $\begin{array}{l}\text { Nasopharyngeal } \\
\text { Carcinoma }\end{array}$ & $\mathrm{PB}$ & RT-PCR & $1020 / 1006$ & rs11614913 \\
\hline 42 & P. Qi [62] & 2015 & Asian & breast cancer & PB & PCR-RFLP & $321 / 290$ & rs11614913, rs3746444 \\
\hline 43 & Panagiotis [63] & 2014 & Caucasian & gastric cancer & $\mathrm{HB}$ & PCR-RFLP & $163 / 480$ & rs11614913 \\
\hline 44 & Pavlakis [64] & 2013 & Caucasian & pancreatic cancer & $\mathrm{HB}$ & PCR-RFLP & $93 / 122$ & rs11614913 \\
\hline 45 & Peng [65] & 2010 & Asian & gastric cancer & $\mathrm{HB}$ & PCR-RFLP & $231 / 213$ & rs11614913 \\
\hline 46 & Qi [66] & 2011 & Asian & $\mathrm{HCC}$ & PB & PCR-LDR & $361 / 391$ & rs11614913 \\
\hline 47 & $\mathrm{Qu}[67]$ & 2014 & Asian & ESCC & HB & PCR-RFLP & $381 / 426$ & rs11614913 \\
\hline 48 & Rama [68] & 2010 & Asian & Bladder Cancer & $\mathrm{PB}$ & PCR-RFLP & $212 / 250$ & rs11614913, rs3746444 \\
\hline 49 & Renata [69] & 2012 & Caucasian & colorectal cancer & $\mathrm{PB}$ & PCR-RFLP & $197 / 212$ & rs11614913 \\
\hline 50 & Roshni [70] & 2014 & Asian & oral cancer & PB & PCR-RFLP & $451 / 452$ & rs11614913 \\
\hline 51 & Serena [71] & 2011 & Caucasian & Lung Cancer & $\mathrm{PB}$ & RT-PCR & $101 / 129$ & rs11614913, rs3746444 \\
\hline 52 & Shen [72] & 2015 & Asian & ESCC & $\mathrm{PB}$ & Hapmap & $1400 / 2185$ & rs11614913, rs3746444 \\
\hline 53 & Sushma [73] & 2015 & Caucasian & $\begin{array}{l}\text { Oral Squamous } \\
\text { Cell Carcinoma }\end{array}$ & $\mathrm{PB}$ & PCR-RFLP & $100 / 102$ & rs11614913, rs3746444 \\
\hline 54 & Tian [74] & 2009 & Asian & lung cancer & $\mathrm{PB}$ & PCR-RFLP & $1058 / 1035$ & rs11614913, rs3746444 \\
\hline 55 & Wang [75] & 2014 & Asian & $\mathrm{HCC}$ & PB & PCR-RFLP & $152 / 304$ & rs 3746444 \\
\hline 56 & $\mathrm{Wu}[76]$ & 2013 & Asian & gastric cancer & $\mathrm{PB}$ & PCR-RFLP & $200 / 211$ & rs 3746444 \\
\hline 57 & Yan [77] & 2015 & Asian & $\mathrm{HCC}$ & PB & PCR-RFLP & $274 / 328$ & rs11614913, rs3746444 \\
\hline 58 & Z.Hu [78] & 2008 & Asian & breast cancer & PB & PCR-RFLP & $1009 / 1093$ & rs11614913, rs3746444 \\
\hline 59 & Zhang [79] & 2013 & Asian & $\begin{array}{l}\text { Acute lymphoblastic } \\
\text { leukemia }\end{array}$ & PB & TaqMan & $570 / 673$ & rs11614913 \\
\hline 60 & Zhao [80] & 2013 & Asian & $\mathrm{HCC}$ & $\mathrm{PB}$ & PCR-RFLP & $235 / 281$ & rs11614913, rs3746444 \\
\hline 61 & Zhou [81] & 2014 & Asian & $\mathrm{HCC}$ & $\mathrm{PB}$ & PCR-RFLP & $266 / 281$ & rs 11614913, rs 3746444 \\
\hline 62 & Zhu [82] & 2011 & Asian & Colorectal Cancer & HB & RT-PCR & $573 / 588$ & rs11614913 \\
\hline
\end{tabular}

HB, hospital based; PB, population based; HCC, hepatocellular carcinoma; ESCC, esophageal squamous cell carcinomar; PCR-RFLP, polymerase chain reaction-restriction fragment length.

polymorphism; PCR-CTPP, polymerase chain reaction with confronting two-pair primers; LDR, ligation detection reaction.

CNKI database. Under conditions prescribed by the inclusion and exclusion criteria, 122 eligible studies (Figure 1) were retrieved, because they were no detailed evaluation. During data extraction, 62 eligible studies [22-83] were leaved, in which 56 and 37 studies were pooled for our meta-analysis, respectively (Figure 1). The characteristics of these selected studies are summarized in Table 1. Among all the included studies, there were 13 studies (hepatocellular cancer), 12 studies (breast), 7 studies (gastric), 6 studies (colorectal), 4 studies (lung), and 20 studies (other cancer types), and one (breast/ovarian cancer). There were 48 studies of Asian population, 14 studies of Caucasian population. Generally speaking, 56 studies included in our meta-analysis with 21958 cases and 26436 controls, which were ultimately analyzed for miR-196a2C.T (rs11614913), 37 studies including 13759 cases and 17946 controls for miR-499 A.G(rs3746444) .

\section{Quantitative synthesis}

\section{miR-196a2C.T (rs11614913)}

For miR-196a2C.T rs11614913 polymorphism, our mate-analysis contain 56 studies (21958 cases and 26436 controls). We observed the $\mathrm{T}$ allele frequency via different 
ethnicities (Asian: 0.93, 95\% CI =0.91-0.96; Caucasian: $0.96,95 \% \mathrm{CI}=0.90-1.02)$.

In the overall analysis, our mate-analysis results manifested a statistically significant association between the miR-196a2C.T rs11614913 and the reduced risks of cancers $\left(\mathrm{OR}=0.93,95 \% \mathrm{CI}=0.91-0.96, \mathrm{P}_{\mathrm{H}}<0.00001\right.$ for $\mathrm{T}$ vs. C), homozygote comparison $(\mathrm{OR}=0.88,95 \%$ $\mathrm{CI}=0.83-0.93, \mathrm{P}_{\mathrm{H}}<0.00001$ for TT vs. CC), dominant model $\left(\mathrm{OR}=0.92,95 \% \mathrm{CI}=0.89-0.96, \mathrm{P}_{\mathrm{H}}<0.00001\right.$ for $\mathrm{TT}+\mathrm{CT}$ vs. CC) and recessive model $(\mathrm{OR}=0.94,95 \%$ $\mathrm{CI}=0.90-0.98, \mathrm{P}_{\mathrm{H}}<0.00001$ for $\mathrm{TT}$ vs. $\left.\mathrm{CC}+\mathrm{CT}\right)$ (Supplementary Table 1).

In subgroup analysis by cancer types, we found the significant associations between the miR-196a2C.T rs11614913 and colorectal cancer $(\mathrm{OR}=1.21,95 \%$ $\mathrm{CI}=1.11-1.33, \mathrm{P}_{\mathrm{H}}<0.00001$ for $\mathrm{T}$ vs. $\mathrm{C}$; $\mathrm{OR}=1.45$, $95 \% \mathrm{CI}=1.21-1.74, \mathrm{P}_{\mathrm{H}}<0.00001$ for TT vs.CC; OR $=1.25,95 \% \mathrm{CI}=1.06-1.46, \mathrm{P}_{\mathrm{H}}<0.00001$ for $\mathrm{CT}$ vs. $\mathrm{CC} ; \mathrm{OR}=1.23,95 \% \mathrm{CI}=1.05-1.43, \mathrm{P}_{\mathrm{H}}<0.00001$ for TT + TC vs. CC; OR $=1.72,95 \% \mathrm{CI}=1.50-1.98, \mathrm{P}_{\mathrm{H}}<$ 0.00001 for TT vs. CC/TC); lung cancer $(\mathrm{OR}=0.89,95 \%$ $\mathrm{CI}=0.82-0.97, \mathrm{P}_{\mathrm{H}}=0.008$ for $\mathrm{T}$ vs. $\mathrm{C} ; \mathrm{OR}=0.79,95 \%$
$\mathrm{CI}=0.67-0.94, \mathrm{P}_{\mathrm{H}}=0.26$ for TT vs. $\mathrm{CC} ; \mathrm{OR}=0.84,95 \%$ $\mathrm{CI}=0.74-0.96, \mathrm{P}_{\mathrm{H}}=0.2$ for $\mathrm{TT}$ vs. $\left.\mathrm{CC}+\mathrm{TC}\right)$; gastric cancer $\left(\mathrm{OR}=0.77,95 \% \mathrm{CI}=0.69-0.85, \mathrm{P}_{\mathrm{H}}<0.00001\right.$ for T vs. $\mathrm{C} ; \mathrm{OR}=0.54,95 \% \mathrm{CI}=0.45-0.66, \mathrm{P}_{\mathrm{H}}<0.00001$ for TT vs. $\mathrm{CC} ; \mathrm{OR}=0.63,95 \% \mathrm{CI}=0.52-0.75, \mathrm{P}_{\mathrm{H}}<0.00001$ for $\mathrm{CT}$ vs. $\mathrm{CC}$; $\mathrm{OR}=0.66,95 \% \mathrm{CI}=0.56-0.77, \mathrm{P}_{\mathrm{H}}<$ 0.00001 for $\mathrm{TT}+\mathrm{CT}$ vs. $\mathrm{CC}$; $\mathrm{OR}=0.76,95 \% \mathrm{CI}=0.65$ $0.89, \mathrm{P}_{\mathrm{H}}<0.00001$ for TT vs. CC $\left.+\mathrm{TC}\right)$. In addition, we also found the decreased risks in other cancer types (OR $=0.86,95 \% \mathrm{CI}=0.82-0.90, \mathrm{P}_{\mathrm{H}}<0.00001$ for $\mathrm{T}$ vs. $\mathrm{C}$; $\mathrm{OR}=0.90,95 \% \mathrm{CI}=0.83-0.98, \mathrm{P}_{\mathrm{H}}<0.00001$ for TT vs. $\mathrm{CC}$; OR $=0.90,95 \% \mathrm{CI}=0.84-0.97, \mathrm{P}_{\mathrm{H}}<0.00001$ for $\mathrm{TT}+\mathrm{CT}$ vs. CC; OR $=0.87,95 \% \mathrm{CI}=0.81-0.93, \mathrm{P}_{\mathrm{H}}$ $<0.00001$ for TT vs. CC + TC ) (Figure 2). Subgroup analysis by the ethnicity revealed a significant association in the comparison of $\mathrm{T}$ vs.C $(\mathrm{OR}=0.93,95 \% \mathrm{CI}=$ $\left.0.91-0.96, \mathrm{P}_{\mathrm{H}}<0.00001\right)$, TT vs. CC (OR $=0.87,95 \%$ $\left.\mathrm{CI}=0.82-0.92, \mathrm{P}_{\mathrm{H}}<0.00001\right)$, TT vs. $\mathrm{CC}+\mathrm{TC}$ $\left(\mathrm{OR}=0.91,95 \% \mathrm{CI}=0.87-0.95, \mathrm{P}_{\mathrm{H}}<0.00001\right)$ in the Asian (Figure 3). Subgroup analysis by the source of control indicated a decreased risk in hospital based study, as showed in Supplementary Table 1.

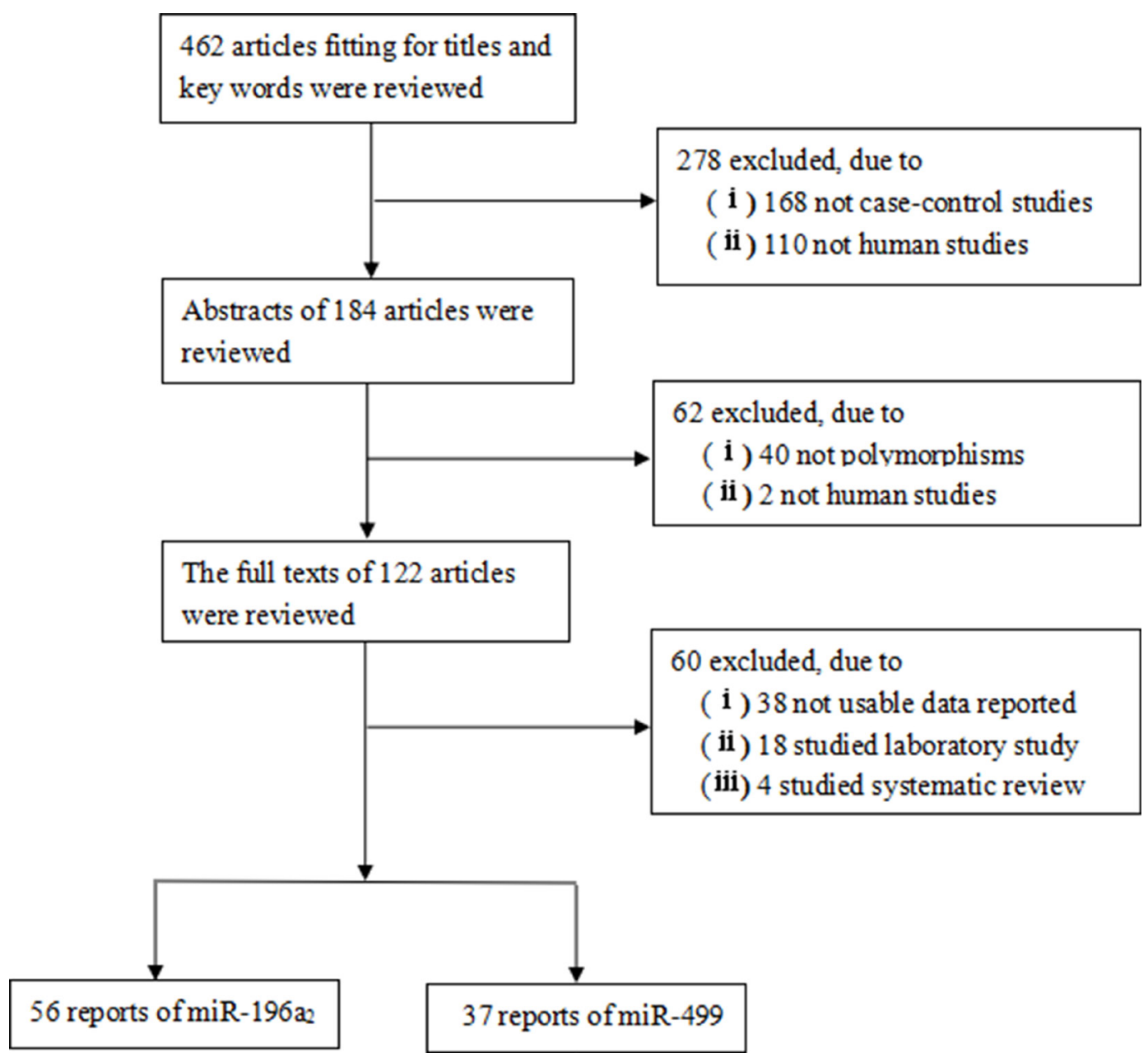

Figure 1: Flow chart of the study selection process. 


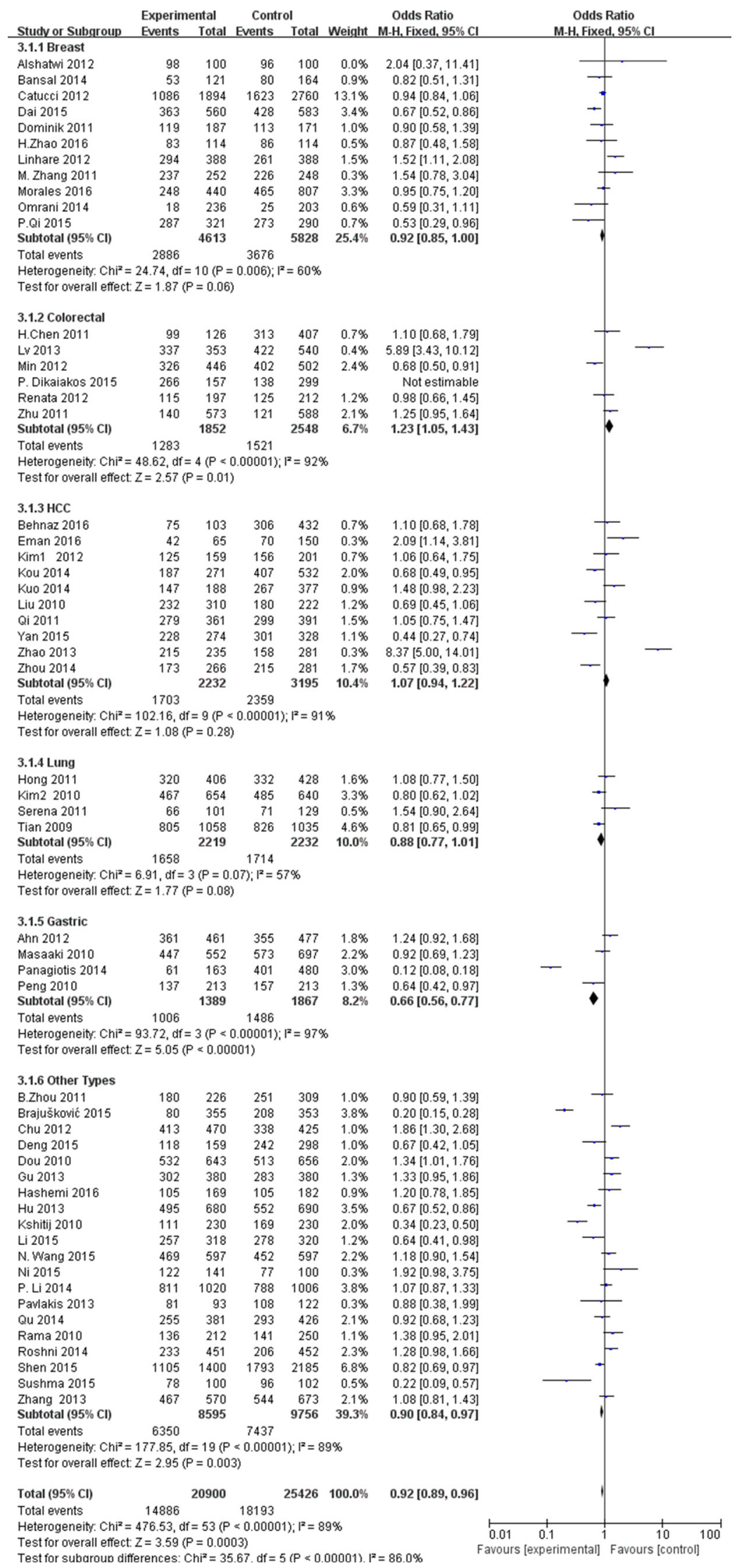

Figure 2: Forest plot of cancer risk in different cancer types associated with miR-196a2 rs11614913 polymorphism for recessive model (TT + TC vs. CC). 


\section{miR-499 A.G rs3746444}

For miR-499A.G rs3746444, our mate-analysis included 37 studies (13759 cases and 17946 controls). our mate-analysis results are showed in Supplementary Table 2. On the whole, we found that miR-499A.G rs3746444 was significantly associated with decreased risks of cancers under the $\mathrm{G}$ vs. $\mathrm{A}(\mathrm{OR}=1.14,95 \%$ $\left.\mathrm{CI}=1.09-1.19, \mathrm{P}_{\mathrm{H}}<0.00001\right), \mathrm{GG}$ vs. $\mathrm{AA}(\mathrm{OR}=$ $\left.1.20,95 \% \mathrm{CI}=1.08-3.11, \mathrm{P}_{\mathrm{H}}<0.001\right), \mathrm{AG}$ vs. $\mathrm{AA}$ $\left(\mathrm{OR}=1.06,95 \% \mathrm{CI}=1.01-1.11, \mathrm{P}_{\mathrm{H}}<0.00001\right.$ for $)$, $\mathrm{GG}+\mathrm{GA}$ vs. $\mathrm{AA}(\mathrm{OR}=1.16,95 \% \mathrm{CI}=1.08-1.25$, $\left.\mathrm{P}_{\mathrm{H}}=0.07\right)$ and $\mathrm{GG}$ vs. $\mathrm{AG}+\mathrm{AA}(\mathrm{OR}=1.20,95 \%$ $\left.\mathrm{CI}=1.09-1.33, \mathrm{P}_{\mathrm{H}}<0.00001\right)$.

In stratified analysis according to cancer types, we investigated the significant associations with breast cancer were only maintained under the $\mathrm{G}$ vs. A $(\mathrm{OR}=1.18,95 \%$ $\left.\mathrm{CI}=1.09-1.27, \mathrm{P}_{\mathrm{H}}=0.04\right), \mathrm{GG}$ vs. $\mathrm{AA}(\mathrm{OR}=1.29,95 \%$ $\left.\mathrm{CI}=1.08-1.56, \mathrm{P}_{\mathrm{H}}=0.04\right), \mathrm{GG}+\mathrm{GA}$ vs. $\mathrm{AA}(\mathrm{OR}=1.29$, $\left.95 \% \mathrm{CI}=1.08-1.54, \mathrm{P}_{\mathrm{H}=} 0.02\right)$ and $\mathrm{GG}$ vs. $\mathrm{AG}+\mathrm{AA}$ $\left(\mathrm{OR}=1.18,95 \% \mathrm{CI}=1.08-1.29, \mathrm{P}_{\mathrm{H}}=0.18\right)$. However, no statistically significant association was found in colorectal, lung, liver or other types cancers (Figure 4). Subgroup analysis according to ethnicity, significant associations with increased risks of cancers were found in Asian population $\left(\mathrm{OR}=1.13,95 \% \mathrm{CI}=1.08-1.19, \mathrm{P}_{\mathrm{H}}<0.00001\right.$ for $\mathrm{G}$ vs. $\mathrm{A} ; \mathrm{OR}=1.19,95 \% \mathrm{CI}=1.06-1.34, \mathrm{P}_{\mathrm{H}}=0.006$ for $\mathrm{GG}$ vs. $\mathrm{AA} ; \mathrm{OR}=1.17,95 \% \mathrm{CI}=1.04-1.32, \mathrm{P}_{\mathrm{H}=} 0.01$ for $\mathrm{GG}+\mathrm{GA}$ vs. $\mathrm{AA}$; OR $=1.12,95 \% \mathrm{CI}=1.06-1.19, \mathrm{P}_{\mathrm{H}}$ $<0.00001$ for GG vs. $\mathrm{AG}+\mathrm{AA})$, and in Caucasian $(\mathrm{OR}=$ $1.16,95 \% \mathrm{CI}=1.06-1.26, \mathrm{P}_{\mathrm{H}}<0.00001$ for $\mathrm{G}$ vs. $\mathrm{A}$; OR $=1.29,95 \% \mathrm{CI}=1.07-1.57, \mathrm{P}_{\mathrm{H}}<0.00001$ for $\mathrm{GG}+\mathrm{GA}$ vs. $\mathrm{AA} ; \mathrm{OR}=1.16,95 \% \mathrm{CI}=1.04-1.29, \mathrm{P}_{\mathrm{H}}=0.001$ for GG vs. AG + AA) (Figure 5). According to study design, we found significant association between population-based studies with elevated risks of cancer $(\mathrm{OR}=1.15,95 \%$ $\mathrm{CI}=1.10-1.20, \mathrm{P}_{\mathrm{H}}<0.00001$ for $\mathrm{G}$ vs. $\mathrm{A} ; \mathrm{OR}=1.22$, $95 \% \mathrm{CI}=1.09-1.36, \mathrm{P}_{\mathrm{H}}<0.00001$ for GG vs. AA; OR $=1.14,95 \% \mathrm{CI}=1.08-1.20, \mathrm{P}_{\mathrm{H}}<0.00001$ for $\mathrm{GG}+\mathrm{GA}$ vs. $\mathrm{AA} ; \mathrm{OR}=1.14,95 \% \mathrm{CI}=1.08-1.20, \mathrm{P}_{\mathrm{H}}<0.00001$ for $\mathrm{GG}$ vs. AG + AA), but the hospital-based studies was not observed a significant association summarized in Supplementary Table 2.

\section{Sensitivity analysis}

In the sensitivity analysis, each study involved in our meta-analysis was deleted the influence of the individual data on the coalescent ORs. The results of sensitivity analysis showed no obvious effects in overall population.

\section{Publication bias}

Begg's funnel plot and Egger's test were undertaken to evaluate the potential publication bias for this study. The shape of the Begg's funnel plots revealed no obvious asymmetry in all genotypes in overall population (Figures 6 and 7). The Egger's test did not reveal publication bias $(P>0.05)$.

\section{DISCUSSION}

The most common form of genetic sequence variation, SNPs are affecting miRNAs sequence coding, splicing and expression such as miRNA gene in human genome, which can affect the susceptibility of cancer including Asian and Caucasian [83]. It was detected in much previous research effort that the role of SNPs is located in miRNA sequence of miR-196a2 C.T (rs11614913) and miR-499 A.G (rs3746444) and influences on the progression of cancers [84]. Recently, several studies have investigated genetic variants of the miRNA SNPs in cancer susceptibility, but conclusions of those studies remain inconclusive. In this study, we conducted a meta-analysis to evaluated the association between the overall cancers susceptibility and the two polymorphisms in miRNA (miR-196a2 C.T rs11614913, miR-499 A.G rs3746444).

For miR-196a2 C.T rs 11614913 polymorphism, although previous studies have revealed no association between cancer susceptibility and the expression of miR-196a2 rs11614913 [85-86]. Recently, the results of these meta-analysis studies have indicated a significant association between cancers susceptibility and miR196a2 C.T rs11614913 [87-92]. The SNPs of miR-196a2 have caused increasing attention because they influence on the maturation progression and mutation of miRNA, and they play potential roles in tumor development and progression(cell proliferation, differentiation, apoptosis, migration and invasion). The predecessor found that the genetic sequence variation in miR-196a2 C.T rs11614913 is located in the $3^{\prime}$ passenger (3p) mature sequence of miR-196a2, and this functional polymorphism is reportedly associated with the susceptibility of multiple kind of tumors (lung cancer and breast cancer). However, there was lower survival rates in small cell lung cancer, gliomas, gastric cancer, gallbladder, head and neck, esophageal, and HCC . During this interim of more than one year, some relevant case-control studies have been published, while conclusions of the relevant studies remain incomprehensive and inconsistent. For example, Dai et al. [32] results revealed that the miR-499 A.G rs3746444 polymorphisms are related to increased risks of breast cancer, while the miR-196a2 C.T rs 11614913 polymorphisms are connected with reduced risks of breast cancer. Wei's studies [93] suggested that the miR$196 \mathrm{a} 2$ C.T rs11614913 might not be connected with susceptibility to gastric cancer, while our study revealed that the miR-196a2 C.T rs11614913 decrease risks to cancer, especially colorectal and gastric cancer in Asians population, and that the miR-499A.G rs3746444 may increase risks of cancer. In subgroup analysis by cancer 


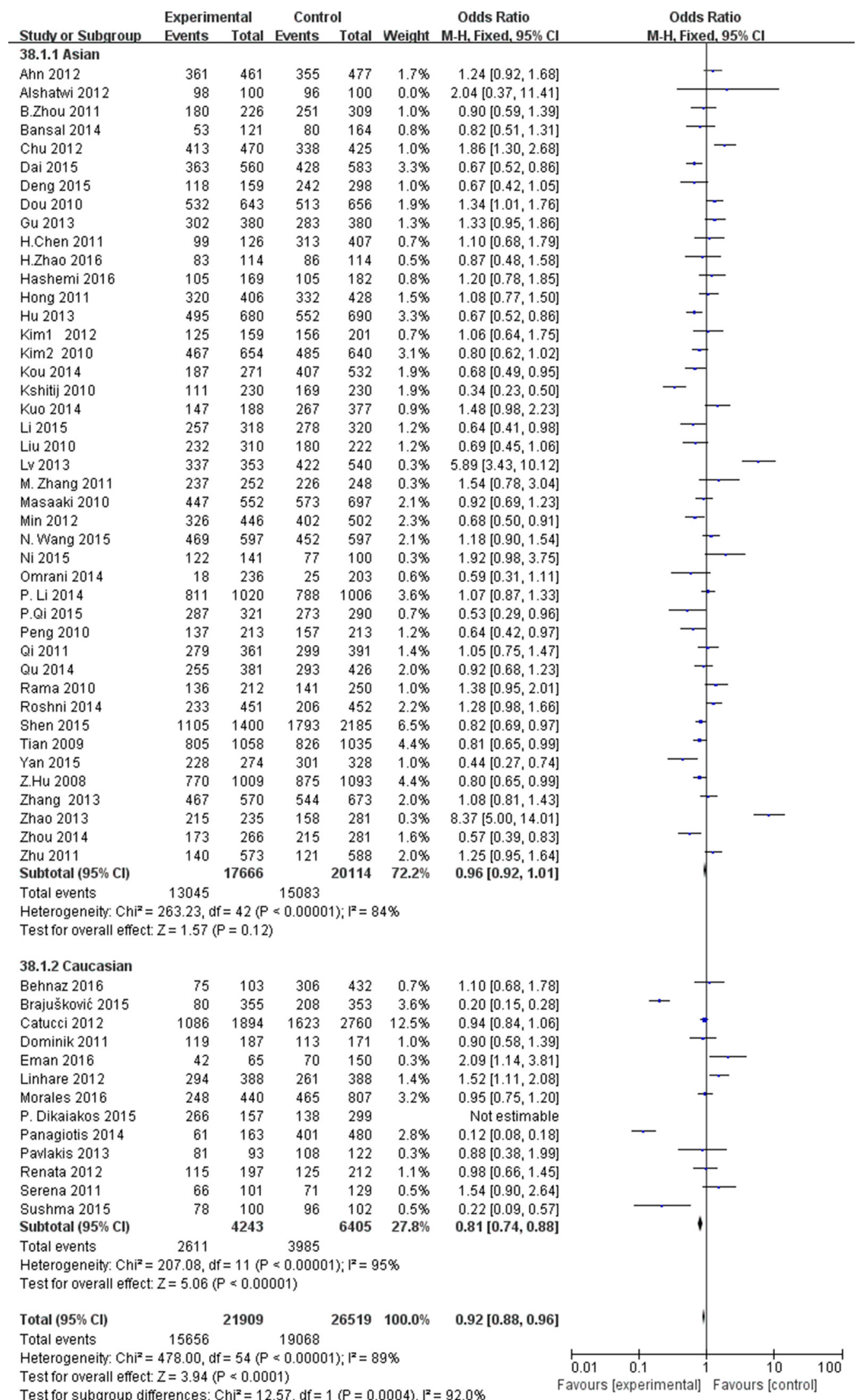

Figure 3: Forest plot of cancer risk in different ethnicity associated with miR-196a2 rs11614913 polymorphism for recessive model (TT+TC vs. CC). 


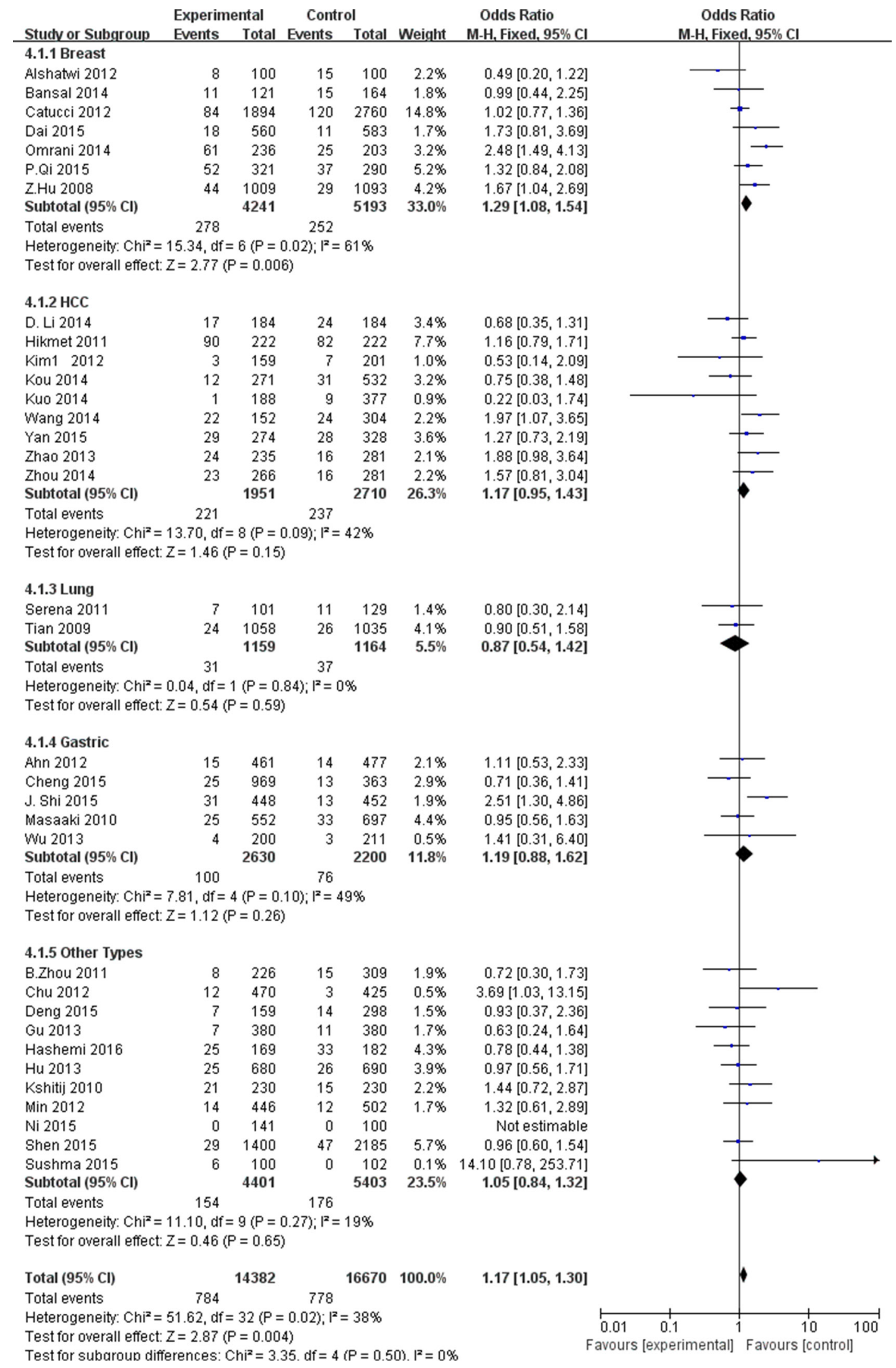

Figure 4: Forest plot of cancer risk in different cancer types associated with miR-499 rs3746444 polymorphism for recessive model (GG+GA vs. AA). 
type, ours results indicate that significant association with risks of cancer was observed in colorectal, gastric and lung cancer. But we did not detect significant association in breast cancer. While Christensen et al. [94] showed the miR-196a2C.T rs11614913 may reduced incidence of breast cancer. In subgroup analysis according to ethnicity, we found the significant association with risks of cancer in Asian population, indicating a possible role of differences in genetic backgrounds between Asians and Caucasians.

As for miR-499A.G rs3746444 polymorphism, the pooled results studies revealed that the miR-499A.G rs3746444 was association with risks of cancer in multiple types of cancer [95-97]. Several studies showed that a large amount of miRNAs are abnormally expressed in various cancers, and Zhang et al. [98] found that approximately 50\% miRNA genes are located in cancerassociated regions, so miRNAs possibly exert a signifcant effect on the tumorigenesis. It was reported that studies have shown that the miR-499 rs3746444 can regulate the expression of SOX genes. The over-expression of SOX6 could reverse the anti-apoptosis effects of miR-499 A.G rs3746444 [99]. The abnormal expression of SOX genes can activate Wnt/ $\beta$-catenin signaling pathway, which is associated with tumorigenesis and progression, so

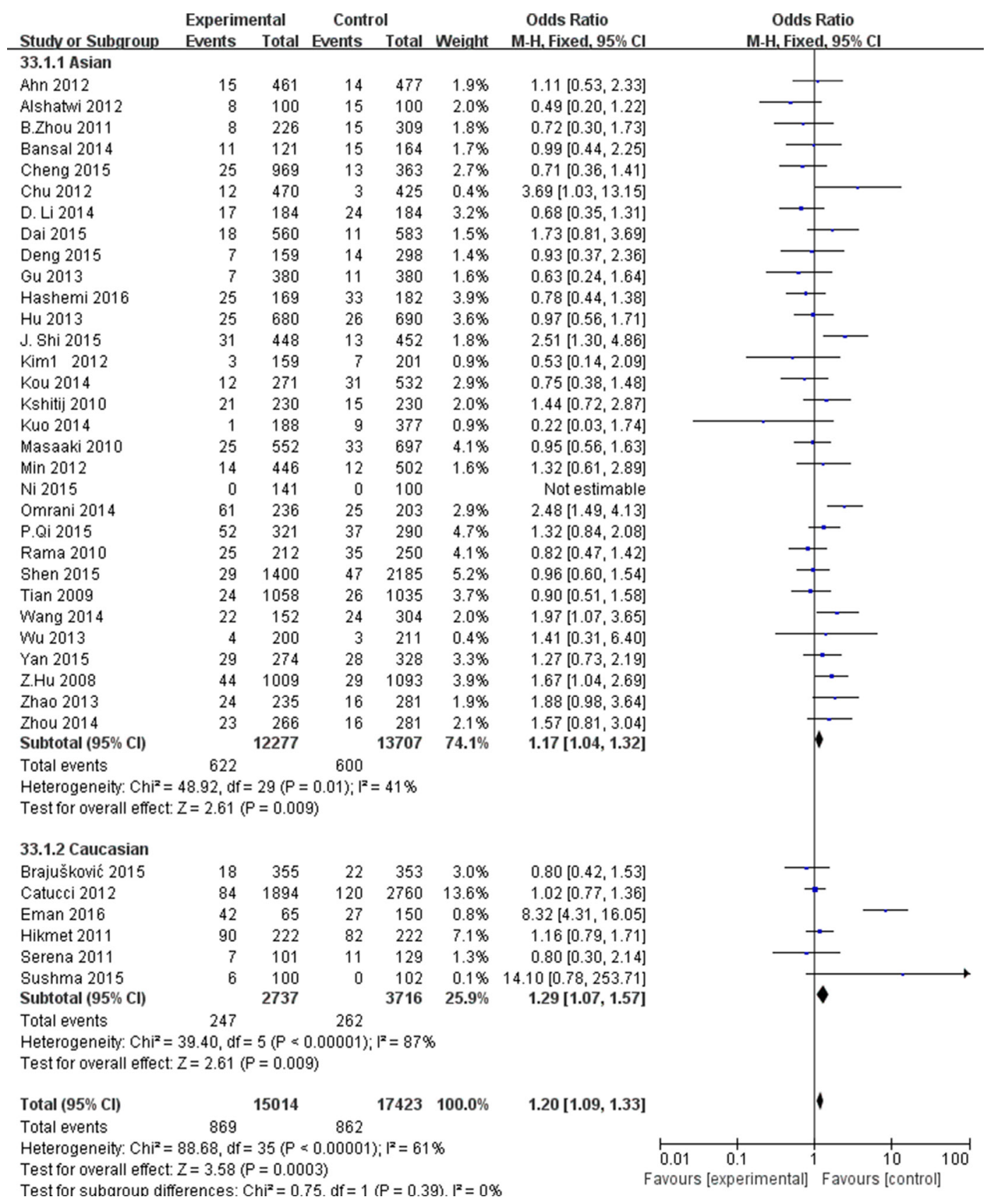

Figure 5: Forest plot of cancer risk in different ethnicity associated with miR-499 rs3746444 polymorphism for recessive model (GG+GA vs. AA). 


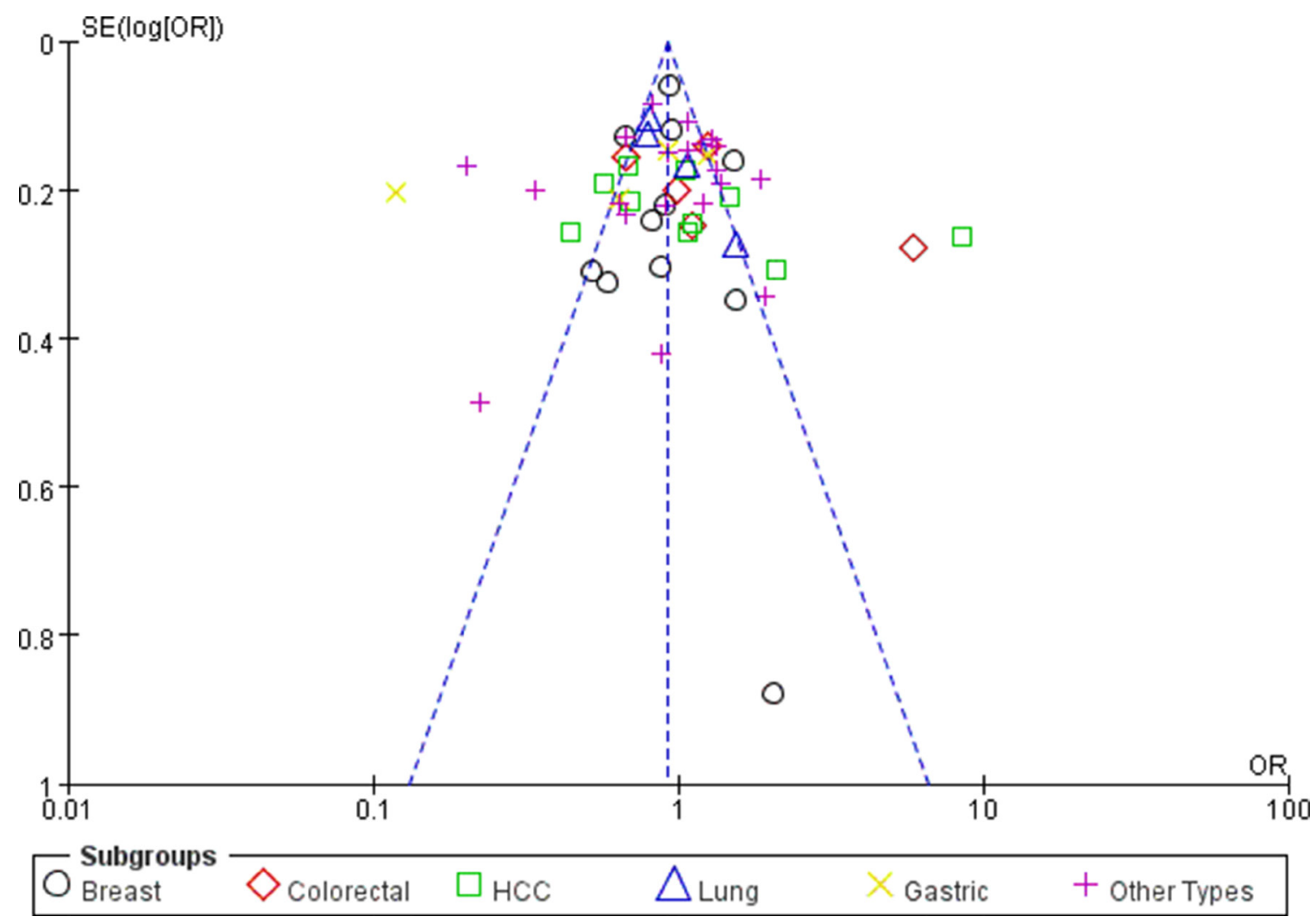

Figure 6: Funnel plot assessing evidence of publication bias (miR-196a2 rs11614913 (TT+TC vs. CC)).

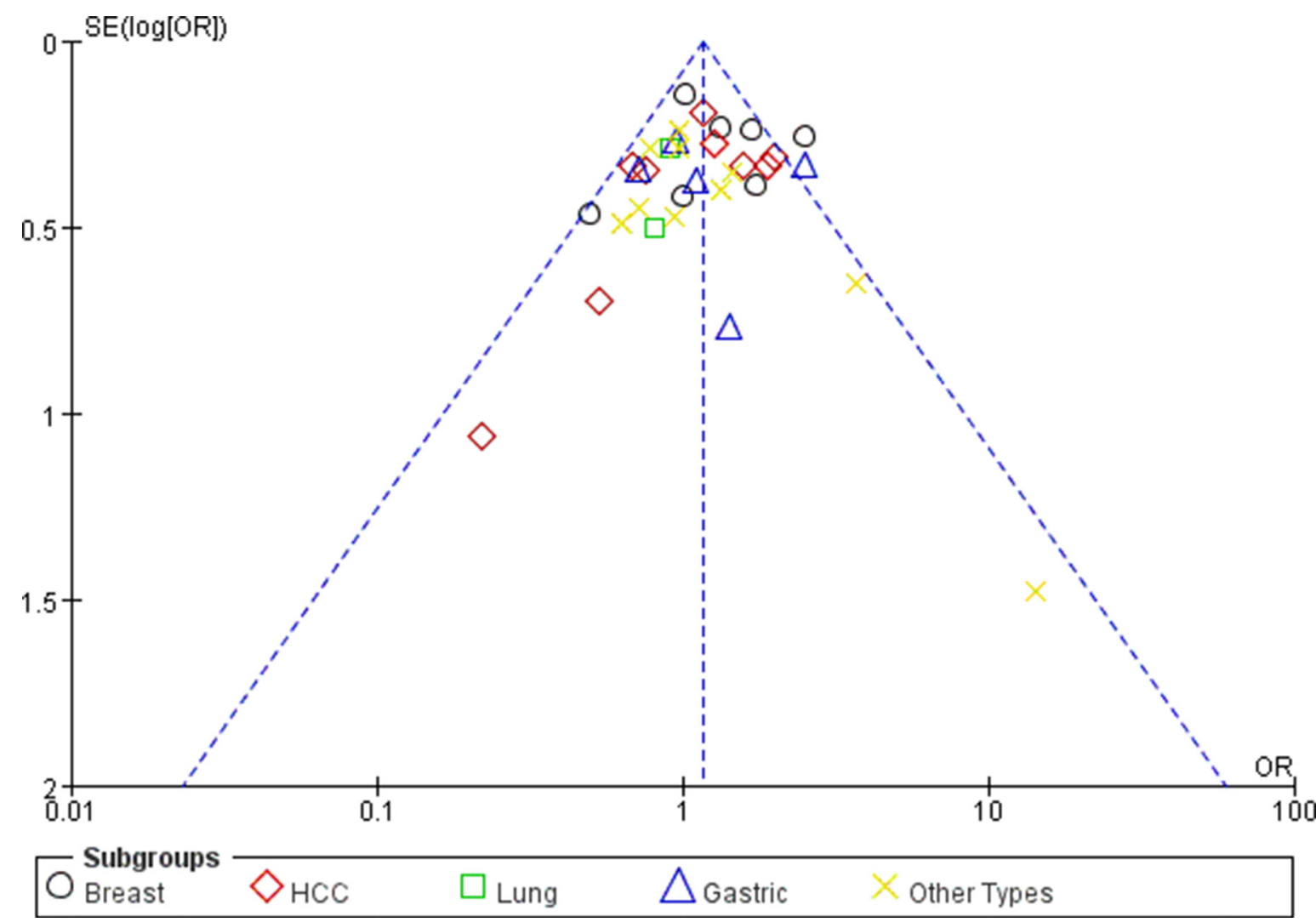

Figure 7: Funnel plot assessing evidence of publication bias (miR-499 rs3746444 (GG+GA vs. AA)). 
miR-499 A.G rs3746444 may play a decisive role in the occurring of cancer by altering SOX genes' expression level. Moreover, the mate-analysis results from 37 studies revealed that the miR-499 $\mathrm{rs} 3746444 \mathrm{G}$ allele was revealed as a risk factor for cancers, in particular, for breast cancer or for in the Asian, which consistent with Hu's results [100]. Therefore, The results illustrated that cancer types and district classification could cause different effects between miR-499 A.G rs3746444 polymorphism and risks of cancer.

To our knowledge, the source of the heterogeneity, including miR-196a 2 C.T rs11614913 and miR499A.G rs3746444, were mainly results from different ethnicity, different cancer types, different source of controls, different selection of subjects and sample size. Therefore, we evaluated the source of heterogeneity by cancer types, ethnicity, different selection of subjects and sample size. Nevertheless, our meta-analysis indeed exist some boundedness. Firstly, lack of relevant published data from the collected studies of potential gene-to-gene and gene-to-environment interactions, which may adjust risks of cancer. Secondly, potential heterogeneity was detected in some comparison, because they are unavoidable. Finally, publication bias existed in studies.

In conclusion, our meta-analysis indicated that the miR-196a2 C.T rs11614913 is significantly associated with a decreased risk of cancers, especially in the subgroup of colorectal, lung and gastric cancer, or Asians. Contrary to the above, the miR-499A.G rs3746444 most likely contributes to increased susceptibility of cancer in overall population, especially in breast cancer. Furthermore, more well-designed researches with large sample size are still necessary to elucidate the correlation between polymorphisms and different kinds of cancers risk.

\section{ACKNOWLEDGMENTS}

Wanjun Yan and Shuqun Zhang designed and wrote this article. Wanjun Yan and Shuqun Zhang screened out relevant articles and extracted data. Wanjun Yan, Xiaoyan Gao, and Shuqun Zhang analyzed data. Wanjun Yan and Shuqun Zhang revised this article.

\section{CONFLICTS OF INTEREST} work.

The authors have no conflicts of interest in this

\section{GRANT SUPPORT}

This study was supported by National Natural Science Foundation, People's Republic of China (No. 81274136) and Program for New Century Excellent Talents in University of China (No. NCET-110439).

\section{REFERENCES}

1. Siegel R, Naishadham D, Jemal A. Cancer statistics, 2012. CA Cancer J Clin. 2012; 62:10-29.

2. Ferlay J, Soerjomataram I, Dikshit R, Eser S, Mathers C, Rebelo M, Parkin DM, Forman D, Bray F. Cancer incidence and mortality worldwide: sources, methods and major patterns in GLOBOCAN 2012. Int J Cancer. 2015; 136:E359-86.

3. Paul L, Niels VH, Pia KV, Anastasia MS, Jaakko K, Markku K, Eero P, Axel Skytthe MS, Kari H. Environmental and heritable factors in the causationof cancer-analyses of cohorts of twins from Sweden, Denmark, and Finland. N Engl J Med. 2000; 343:78-85.

4. Ambros V. The functions of animal microRNAs. Nature. 2004; 431:350-55.

5. Bartel DP. MicroRNAs: genomics, biogenesis, mechanism, and function. Cell. 2004; 116:281-97.

6. He L, Hannon GJ. MicroRNAs: small RNAs with a big role in gene regulation. Nat Rev Genet. 2004; 5:522-31.

7. Zhang B, Pan X, Cobb GP, Anderson TA. microRNAs as oncogenes and tumor suppressors. Dev Biol. 2007; 302:1-12.

8. Saunders MA, Liang H, Li WH. Human polymorphism at microRNAs and microRNA target sites. Proc Natl Acad Sci USA. 2007; 104:3300-05.

9. Chen K, Song F, Calin GA, Wei Q, Hao X, Zhang W. Polymorphisms in microRNA targets: a gold mine for molecular epidemiology. Carcinogenesis. 2008; 29:1306-11.

10. Tian T, Shu Y, Chen J, Hu Z, Xu L, Jin G, Liang J, Liu P, Zhou X, Miao R, Ma H, Chen Y, Shen H. A functional genetic variant in microRNA-196a2 is associated with increased susceptibility of lung cancer in Chinese. Cancer Epidemiol Biomarkers Prev. 2009; 18:1183-87.

11. Min KT, Kim JW, Jeon YJ, Jang MJ, Chong SY, Oh D, Kim NK. Association of the miR-146aC $>\mathrm{G}, 149 \mathrm{C}>\mathrm{T}, 196 \mathrm{a} 2 \mathrm{C}>\mathrm{T}$, and $499 \mathrm{~A}>\mathrm{G}$ polymorphisms with colorectal cancer in the Korean population. Mol Carcinog. 2012; 51:E65-73.

12. Li XD, Li ZG, Song XX, Liu CF. A variant in microRNA$196 \mathrm{a} 2$ is associated with susceptibility to hepatocellular carcinoma in Chinese patients with cirrhosis. Pathology. 2010; 42:669-73.

13. Hu Z, Liang J, Wang Z, Tian T, Zhou X, Chen J, Miao R, Wang Y, Wang X, Shen H. Common genetic variants in premicroRNAs were associated with increased risk of breast cancer in Chinese women. Hum Mutat. 2009; 30:79-84.

14. Okubo M, Tahara T, Shibata T, Yamashita H, Nakamura M, Yoshioka D, Yonemura J, Ishizuka T, Arisawa T, Hirata I. Association between common genetic variants in premicroRNAs and gastric cancer risk in Japanese population. Helicobacter. 2010; 15:524-31.

15. Chu YH, Tzeng SL, Lin CW, Chien MH, Chen MK, Yang SF. Impacts of microRNA gene polymorphisms on the susceptibility of environmental factors leading to carcinogenesis in oral cancer. PLoS One. 2012; 7:e39777. 
16. Dou TH, Wu QH, Chen X, Ribas J, Ni XH, Tang C, Huang FP, Zhou LF, Lu DR. A polymorphism of microRNA196a genome regionwas associated with decreased risk of glioma in Chinese population. J Cancer Res Clin Oncol. 2010; 136:1853-59.

17. George GP, Gangwar R, Mandal RK, Sankhwar SN, Mittal RD. Genetic variation in microRNA genes and prostate cancer risk in North Indian population. Mol Biol Rep. 2011; 38:1609-15.

18. DerSimonian R, Kacker R. Random-effects model for metaanalysis of clinical trials: an update. Contemp Clin Trials. 2007; 28:105-14.

19. Mantel N, Haenszel W. Statistical aspects of the analysis of data from retrospective studies of disease. J Natl Cancer Inst. 1959; 22:719-48.

20. Tobias A. Assessing the influence of a single study in the metaanalysis estimate. Stata Technical Bulletin. 1999; 15-17.

21. Egger M, Davey Smith G, Schneider M, Minder C. Bias in meta-analysis detected by a simple, graphical test. BMJ. 1997; 315:629-34.

22. Ahn DH, Rah HC, Choi YK. Association of the miR$146 \mathrm{aC}>\mathrm{G}$, miR-149T $>$ C,miR-196a2T $>$ C, and miR-499A $>\mathrm{G}$ Polymorphisms With Gastric Cancer Risk and Survival in the Korean Population. Mol Carcinog. 2013; 52:E39-51.

23. Ali AA, Gowhar S, Hasan TN, Naveed AS, Amal AA, Mohammed A, Abdulaziz AA. Differential Expression Profileand Genetic Variants of MicroRNAs Sequences in Breast Cancer Patients. PLoS One. 2012; 7:e30049.

24. Zhou B, Wang K, Wang Y, Xi M, Zhang Z, Song Y, Zhang L. Common genetic polymorphisms in pre-microRNAs and risk of cervical squamous cell carcinoma. Mol Carcinog. 2011; 50:499-505.

25. Bansal C, Sharma KL, Misra S, Srivastava AN, Mittal B, Singh US. Common genetic variants in pre-microRNAs and risk ofbreast cancer in the North Indian population. Ecancermedicalscience. 2014; 8: 473.

26. Riazalhosseini B, Mohamed Z, Apalasamy YD, Eng HS, Mohamed R. Association between microRNA-196A2 and microRNA-146A polymorphisms and progression to cirrhosis and hepatocellular carcinoma in patients with viral hepatitis B. Pharmacogenet Genomics. 2016; 26:74-79.

27. Nikolić Z, Savić Pavićević D, Vučić N, Cidilko S, Filipović N, Cerović S, Vukotić V, Romac S, Brajušković G. Assessment of association between genetic variants in microRNA genes hsa-miR-499, hsa-miR-196a2 and hsamiR-27a and prostate cancer risk in Serbian population. Exp Mol Pathol. 2015; 99:145-50.

28. Kim WH, Min KT, Jeon YJ, Kwon CI, Ko KH, Park PW, Hong SP, Rim KS, Kwon SW, Hwang SG, Kim NK. Association study of microRNA polymorphisms with hepatocellular carcinoma in Korean population. Gene. 2012; 504:92-97.

29. Cai M, Zhang Y, Ma Y, Li W, Min P, Qiu J, Xu W, Zhang M, Li M, Li L, Liu Y, Yang D, Zhang J, Cheng F. Association between microRNA-499 polymorphism and gastric cancer risk in Chinese population. Bull Cancer. 2015; 102:973-78.

30. Chu YH, Tzeng SL, Lin CW, Chien MH, Chen MK, Yang SF. Impacts of microRNA gene polymorphisms on the susceptibility of environmental factors leading to carcinogenesis in oral cancer. PLoS One. 2012; 7:e39777.

31. Li D, Peng JJ, Tan Y, Chen T, Wei D, Du M, Zhang T. Genetic variations in microRNA genes and susceptibility to hepatocellular carcinoma. Genet Mol Res. 2015; 14:1926-31.

32. Dai ZM, Kang HF, Zhang WG, Li HB, Zhang SQ, Ma XB, Lin S, Wang M, Feng YJ, Liu K, Liu XH, Xu P, Dai J. The Associations of Single NucleotidePolymorphisms in miR196a2, miR-499, and miR-608 With Breast Cancer Susceptibility. Medicine. 2016; 95:e2826.

33. Dominik J, Gabrovska PN, Stephen RW. Single NucleotidePolymorphism in hsa-mir-196a-2 and Breast Cancer Risk: A Case Control Study. Twin Res Hum Genet. 2014; 417-421.

34. Dou T, Wu Q, Chen X, Ribas J, Ni X, Tang C, Huang F, Zhou L, Lu D. A polymorphism of microRNA196a genome region was associated with decreased risk of glioma in Chinese population. J Cancer Res Clin Oncol. 2010; 136:1853-59.

35. Toraih EA, Fawz MS, Elgazzaz MG, Hussein MH, Shehata RH, Daoud HG. Combined Genotype Analyses of Precursor miRNA196a2 and 499a Variants with Hepatic and Renal Cancer Susceptibility a Preliminary Study. Asian Pac J Cancer Prev. 2016; 17:3369-75.

36. Wei J, Zheng L, Liu S, Yin J, Wang L, Wang X, Shi Y, Shao A, Tang W, Ding G, Liu C, Chen S, Gu H. MiR-196a2 rs11614913 $\mathrm{T}>\mathrm{C}$ polymorphism and risk of esophageal cancer in a Chinese population. Hum Immunol. 2013; 74:1199-205.

37. Chen H, Sun LY, Chen LL. A variant in microRNA-196a2 is not associated with susceptibility to and progression of colorectal cancer in Chinese. Intern Med J. 2011; 42: e115-19.

38. Zhao H, Xu J, Zhao D, Geng M, Ge H, Fu L, Zhu Z. Somatic Mutation of the SNP rs11614913 and Its Association with Increased MIR 196A2 Expression in Breast Cancer. DNA Cell Biol. 2016; 35:81-87.

39. Mohsen O, Mohammad H, Ebrahim EN, SeyedShahaboddin H, Mohammad AM, Farshid A, Mohsen T. Hsa-mir-499 rs3746444 gene polymorphism is associatedwith susceptibility to breast cancer in an Iranian population. Biomarkers Med. 2014; 8:259-67.

40. Akkiz H, Bayram S, Bekar A, Akgöllü E, Üsküdar O. Genetic variation in the microRNA-499 gene and hepatocellular carcinoma risk in a Turkish population: lack of any association in a case-control study. Asian Pac J Cancer Prev. 2011; 12:3107-12.

41. Deng S, Wang W, Li X, Zhang P. Common genetic polymorphisms in pre-microRNAs and risk of bladder cancer. World J Surg Oncol. 2015; 13:297.

42. Hu E, Wang D, Zhang X, Li J, Hu Y, Gong H, Liu E. Four common polymorphisms in microRNAs and the risk 
of adult glioma in a Chinese case-control study. J Mol Neurosci. 2013; 51:933-40.

43. Shi J, Liu Y, Liu J, Zhou J. Hsa-miR-449a genetic variant is associated with risk of gastric cancer in a Chinese population. Int J Clin Exp Pathol. 2015; 8:13387-92.

44. Min KT, Kim JW, Jeon YJ, Jang MJ, Chong SY, Oh D, Kim NK. Association of the miR-146aC $>\mathrm{G}, 149 \mathrm{C}>\mathrm{T}, 196 \mathrm{a} 2 \mathrm{C}>\mathrm{T}$, and $499 \mathrm{~A}>\mathrm{G}$ polymorphisms with colorectal cancer in the Korean population. Mol Carcinog. 2012; 51:E65-73.

45. Hong YS, Kang HJ, Kwak JY, Park BL, You CH, Kim YM, Kim H. Association between microRNA196a2 rs11614913 genotypes and the risk of non-small cell lung cancer in Korean population. J Prev Med Public Health. 2011; 44:125-30.

46. Kou JT, Fan H, Han D, Li L, Li P, Zhu J, Ma J, Zhang $\mathrm{ZH}, \mathrm{He} \mathrm{Q}$. Association between four common microRNA polymorphisms and the risk of hepatocellular carcinoma and HBV infection. Oncol Lett. 2014; 8:1255-60.

47. Srivastava K, Srivastava A, Mittal B. Common genetic variants in pre-microRNAs and risk of gallbladder cancer in North Indian population. J Hum Genet. 2010; 55:495-99.

48. Chu YH, Hsieh MJ, Chiou HL, Liou YS, Yang CC, Yang SF, Kuo WH. MicroRNA gene polymorphisms and environmental factors increase patient susceptibility to hepatocellular carcinoma. PLoS One. 2014; 9:e89930.

49. Li T, Niu L, Wu L, Gao X, Li M, Liu W, Yang L, Liu D. A functional polymorphism in microRNA-196a2 is associated with increased susceptibility to non-Hodgkin lymphoma. Tumour Biol. 2015; 36:3279-84.

50. Linhares JJ, Azevedo M Jr, Siufi AA, de Carvalho CV, Wolgien MC, Noronha EC, Bonetti TC, da Silva ID. Evaluation of single nucleotide polymorphisms in microRNAs (hsa-miR-196a2 rs11614913 C/T) from Brazilian women with breast cancer. BMC Med Genet. 2012; 13:119.

51. Li XD, Li ZG, Song XX, Liu CF. A variant in microRNA$196 \mathrm{a} 2$ is associated with susceptibility to hepatocellular carcinoma in Chinese patients with cirrhosis. Pathology. 2010; 42:669-73.

52. Lv M, Dong W, Li L, Zhang L, Su X, Wang L, Gao L, Zhang L. Association between genetic variants in premiRNA and colorectal cancer risk in a Chinese population. J Cancer Res Clin Oncol. 2013; 139:1405-10.

53. Zhang M, Jin M, Yu Y, Zhang S, Wu Y, Liu H, Chen B, Li Q, Ma X, Chen K. Associations of miRNA polymorphisms and female physiological characteristics with breast cancer risk in Chinese population. Eur J Cancer Care (Engl). 2012; 21:274-80.

54. Okubo M, Tahara T, Shibata T, Yamashita H, Nakamura M, Yoshioka D, Yonemura J, Ishizuka T, Arisawa T, Hirata I. Association between common genetic variants in premicroRNAs and gastric cancer risk in Japanese population. Helicobacter. 2010; 15:524-31.

55. Kim MJ, Yoo SS, Choi YY, Park JY. A functional polymorphism in the pre-microRNA-196a2 and the risk of lung cancer in a Korean population. Lung Cancer. 2010; 69:127-29.

56. Morales S, Gulppi F, Gonzalez-Hormazabal P, FernandezRamires R, Bravo T, Reyes JM, Gomez F, Waugh E, Jara L. Association of single nucleotide polymorphisms in PremiR-27a, Pre-miR-196a2, Pre-miR-423, miR-608 and Pre-miR-618 with breast cancer susceptibility in a South American population. BMC Genet. 2016; 17:109.

57. Wang N, Li Y, Zhou RM, Wang GY, Wang CM, Chen ZF, Liu W. Hsa-miR-196a2 functional SNP is associated with the risk of ESCC in individuals under 60 years old. Biomarkers. 2014; 19:43-48.

58. Liu X, Xu B, Li S, Zhang B, Mao P, Qian B, Guo L, Ni P. Association of SNPs in miR-146a, miR-196a2, and miR-499 with the risk of endometrial/ovarian cancer. Acta Biochim Biophys Sin (Shanghai). 2015; 47:564-66.

59. Mohsen O, Mohammad H, Ebrahim EN, SeyedShahaboddin H, Mohammad Ali M, Farshid A, Mohsen T. Hsa-mir-499 rs3746444 genepolymorphism is associatedwith susceptibility to breast cancer in an Iranian population. Biomarkers Med. 2014; 8:259-67.

60. Dikaiakos P, Gazouli M, Rizos S, Zografos G, Theodoropoulos GE. Evaluation of genetic variants in miRNAs in patients with colorectal cancer. Cancer Biomark. 2015; 15:157-62.

61. Li P, Yan H, Zhang H, Yu L, Wang Z, Zhai Y, Xia X, Zhang J, Zhang Y, Ma F, Huang W, Cai M, Cui Y, et al. A functional polymorphism in MIR196A2 is associated with risk and progression of nasopharyngeal carcinoma in the Chinese population. Genet Test Mol Biomarkers. 2014; 18:149-55.

62. Qi P, Wang L, Zhou B, Yao WJ, Xu S, Zhou Y, Xie ZB. Associations of miRNA polymorphisms and expression levels with breast cancer risk in the Chinese population. Genet Mol Res. 2015; 14:6289-96.

63. Dikeakos P, Theodoropoulos G, Rizos S, Tzanakis N, Zografos G, Gazouli M. Association of the miR-146aC $>\mathrm{G}$, miR-149T $>$ C, and miR-196a2T $>$ C polymorphisms with gastric cancer risk and survival in the Greek population. Mol Biol Rep. 2014; 41:1075-80.

64. Pavlakis E, Papaconstantinou I, Gazouli M, Theodosopoulos T, Karamanolis G, Genatas K, Ladas SD. MicroRNA gene polymorphismsin pancreatic cancer. Pancreatology. 2013; 13: $273 \mathrm{e} 278$.

65. Qi P, Dou TH, Geng L, Zhou FG, Gu X, Wang H, Gao CF. Association of a variant in MIR 196A2 with susceptibility to hepatocellular carcinoma in male Chinese patients with chronic hepatitis B virus infection. Hum Immunol. 2010; 71:621-26.

66. Peng S, Kuang Z, Sheng C, Zhang Y, Xu H, Cheng Q. Association of microRNA-196a-2 gene polymorphism with gastric cancer risk in a Chinese population. Dig Dis Sci. 2010; 55:2288-93.

67. Qu Y, Qu H, Luo M, Wang P, Song C, Wang K, Zhang J, Dai L. MicroRNAs related polymorphisms and genetic 
susceptibility to esophageal squamous cell carcinoma. Mol Genet Genomics. 2014; 289:1123-30.

68. Rama DM, Ruchika G, George GP, Tulika M, Rakesh K. Investigative Role of Pre-MicroRNAs in Bladder Cancer Patients: A Case-Control Study in North India. DNA Cell Biol. 2011; 30:401-06.

69. Hezova R, Kovarikova A, Bienertova-Vasku J, Sachlova M, Redova M, Vasku A, Svoboda M, Radova L, Kiss I, Vyzula R, Slaby O. Evaluation of SNPs in miR-196-a2, miR-27a and miR-146a as risk factors of colorectal cancer. World J Gastroenterol. 2012; 18:2827-31.

70. Roy R, De Sarkar N, Ghose S, Paul RR, Pal M, Bhattacharya C, Chowdhury SK, Ghosh S, Roy B. Genetic variations at microRNA and processing genes and risk of oral cancer. Tumour Biol. 2014; 35:3409-14.

71. Vinci S, Gelmini S, Pratesi N, Conti S, Malentacchi F, Simi L, Pazzagli M, Orlando C. Genetic variants in miR-146a, miR-149, miR-196a2, miR-499 and their influence on relative expression in lung cancers. Clin Chem Lab Med. 2011; 49:2073-80.

72. Shen F, Chen J, Guo S, Zhou Y, Zheng Y, Yang Y, Zhang J, Wang X, Wang C, Zhao D, Wang M, Zhu M, Fan L, et al. Genetic variants in miR-196a2 and miR-499 are associated with susceptibility to esophageal squamous cell carcinoma in Chinese Han population. Tumour Biol. 2016; 37:4777-84.

73. Sushma PS, Jamil K, Kumar PU, Satyanarayana U, Ramakrishna M, Triveni B. Genetic Variation in MicroRNAs and Risk of Oral Squamous Cell Carcinoma in South Indian Population. Asian Pac J Cancer Prev. 2015; 16:7589-94.

74. Tian T, Shu Y, Chen J, Hu Z, Xu L, Jin G, Liang J, Liu P, Zhou X, Miao R, Ma H, Chen Y, Shen H. A functional genetic variant in microRNA-196a2 is associated with increased susceptibility of lung cancer in Chinese. Cancer Epidemiol Biomarkers Prev. 2009; 18:1183-87.

75. Wang XH, Wang FR, Tang YF, Zou HZ, Zhao YQ. Association of miR-149C $>\mathrm{T}$ and $\mathrm{miR}-499 \mathrm{~A}>\mathrm{G}$ polymorphisms with the risk of hepatocellular carcinoma in the Chinese population. Genet Mol Res. 2014; 13:5048-54.

76. Wu XJ, Mi YY, Yang H, Hu AK, Li C, Li XD, Zhang QG. Association of the hsa-mir-499 (rs3746444) polymorphisms with gastric cancer risk in the Chinese population. Onkologie. 2013; 36:573-76.

77. Yan P, Xia M, Gao F, Tang G, Zeng H, Yang S, Zhou H, Ding D, Gong L. Predictive role of miR-146a rs2910164 $(\mathrm{C}>\mathrm{G})$, miR-149 rs2292832 (T>C), miR-196a2 rs11614913 $(\mathrm{T}>\mathrm{C})$ and miR-499 rs3746444 $(\mathrm{T}>\mathrm{C})$ in the development of hepatocellular carcinoma. Int J Clin Exp Pathol. 2015; 8:15177-83.

78. Hu Z, Liang J, Wang Z, Tian T, Zhou X, Chen J, Miao R, Wang Y, Wang X, Shen H. Common genetic variants in premicroRNAs were associated with increased risk of breast cancer in Chinese women. Hum Mutat. 2009; 30:79-84.

79. Tong N, Xu B, Shi D, Du M, Li X, Sheng X, Wang M, Chu H, Fang Y, Li J, Wu D, Zhang Z. Hsa-miR-196a2 polymorphism increases the risk of acute lymphoblastic leukemia in Chinese children. Mutat Res. 2014; 759:16-21.

80. Hao YX, Wang JP, Zhao LF. Associations between three common MicroRNA polymorphisms and hepatocellular carcinoma risk in Chinese. Asian Pac J Cancer Prev. 2014; 14:6601-04.

81. Zhou B, Dong LP, Jing XY, Li JS, Yang SJ, Wang JP, Zhao LF. Association between miR-146aG $>C$ and miR$196 \mathrm{a} 2 \mathrm{C}>\mathrm{T}$ polymorphisms and the risk of hepatocellular carcinoma in a Chinese population. Tumour Biol. 2014; 35:7775-80.

82. Zhu L, Chu H, Gu D, Ma L, Shi D, Zhong D, Tong N, Zhang Z, Wang M. A functional polymorphism in miRNA$196 \mathrm{a} 2$ is associated with colorectal cancer risk in a Chinese population. DNA Cell Biol. 2012; 31:350-54.

83. Liu F, Li B, Wei Y, Chen X, Ma Y, Yan L, Wen T. P21 codon 31 polymorphism associated with cancer among white people: evidence from a meta-analysis involving 78,074 subjects. Mutagenesis. 2011; 26:513-21.

84. Ryan BM, Robles AI, Harris CC. Genetic variation in microRNA networks: the implications for cancer research. Nat Rev Cancer. 2010; 10:389-402.

85. Christensen BC, Avissar-Whiting M, Ouellet LG, Butler RA, Nelson HH, McClean MD, Marsit CJ, Kelsey KT. Mature microRNAsequence polymorphism in MIR196A2 is associated with risk and prognosis of head and neck cancer. Clin Cancer Res. 2010; 16:3713-20.

86. Hoffman AE, Zheng T, Yi C, Leaderer D, Weidhaas J, Slack F, Zhang Y, Paranjape T, Zhu Y. microRNA miR-196a-2 and breast cancer: a genetic and epigenetic association study and functional analysis. Cancer Res. 2009; 69:5970-77.

87. Xu W, Xu JI, Liu SF, Chen B, Wang XL, Li Y, Qian Y, Zhao WH, Wu JQ. Effects of common polymorphisms rs11614913 inmiR-196a2 and rs2910164 in miR-146a on cancer susceptibility: a meta-analysis. PLoS One. 2011; 6:e2047121.

88. Chu HY, Wang ML, Shi DN, Ma L, Zhang ZZ, Tong N, Huo XY, Wang W, Luo DW, Gao Y, Zhang ZD. Hsa-miR196a2 Rs11614913 polymorphismcontributes to cancer susceptibility: evidence from 15 case-control studies. PLOS One. 2011; 6:e18108.92.

89. Wang F, Ma YL, Zhang P, Yang JJ, Chen HQ, Liu ZH, Peng JY, Zhou YK, Qin HL. A genetic variant in microRNA$196 \mathrm{a} 2$ is associated with increased cancer risk: a metaanalysis. Mol Biol Rep. 2012; 39:269-75.

90. He BS, Pan YQ, Cho WC, Xu YQ, Gu L, Nie ZL, Chen LP, Song GQ, Gao TY, Li R, Wang SK. The Association between Four Genetic Variants inMicroRNAs (rs11614913, rs2910164, rs3746444, rs2292832) and Cancer Risk: Evidence fromPublished Studies. PLOS ONE. 2012; 7 : e49032.113.

91. Wang J, Wang Q, Liu H, Shao N, Tan B, Zhang G, Wang K, Jia Y, Ma W, Wang N, Cheng Y. The association of miR-146a rs2910164 and miR-196a2 rs11614913 
polymorphisms with cancer risk: a meta-analysis of 32 studies. Mutagenesis. 2012; 27:779-88.

92. Srivastava K, Srivastava A. Comprehensive review of genetic association studies and meta-analyses on miRNA polymorphisms and cancer risk. PLoS One. 2012; 7:e50966.

93. Wei Y, Li L, Gao J. The association between two common polymorphisms (miR-146a rs2910164 and miR-196a2 rs11614913) and susceptibility to gastric cancer: A metaanalysis. Cancer Biomark. 2015; 15:235-48.

94. Xu W, Xu J, Liu S, Chen B, Wang X, Li Y, Qian Y, Zhao W, Wu J. Effects of common polymorphisms rs11614913 in miR-196a2 and rs2910164 in miR-146a on cancer susceptibility: a meta-analysis. PLoS One. 2011; 6:e20471.

95. Min KT, Kim JW, Jeon YJ, Jang MJ, Chong SY, Oh D, Kim NK. Association of the miR-146aC $>$ G, 149C $>$ T, 196a2C $>$ T, and $499 \mathrm{~A}>\mathrm{G}$ polymorphisms with colorectal cancer in the Korean population. Mol Carcinog. 2012; 51:E65-73.

96. Wang P, Xie S, Cui A, Zhang Y, Jiang B. miR-196a2 polymorphisms and susceptibility to cancer: A meta- analysis involving 24,697 subjects. Exp Ther Med. 2012; 3:324-30.

97. Xiang Y, Fan S, Cao J, Huang S, Zhang LP. Association of the microRNA-499 variants with susceptibility to hepatocellular carcinoma in a Chinese population. Mol Biol Rep. 2012; 39:7019-23.

98. Zhang B, Pan X, Cobb GP, Anderson TA. microRNAs as oncogenes and tumor suppressors. Dev Biol. 2007; 302:1-12.

99. Li X, Wang J, Jia Z, Cui Q, Zhang C, Wang W, Chen P, Ma K, Zhou C. MiR-499 regulates cell proliferation and apoptosis during late-stage cardiac differentiation via Sox6 and cyclin D1. PLoS One. 2013; 8:e74504.

100. Hu Z, Liang J, Wang Z, Tian T, Zhou X, Chen J, Miao R, Wang Y, Wang X, Shen H. Common genetic variants in premicroRNAs were associated with increased risk of breast cancer in Chinese women. Hum Mutat. 2009; 30:79-84. 